Jap. J. Limnol. 45, 4, 260-268, 1984.

\title{
Distribution of Minor Metallic Elements in River Water of Green Tuff Region, Yamagata Pref.
}

\author{
Toshikatsu IRIYE
}

\begin{abstract}
The concentrations of 7 minor heavy metallic elements ( $\mathrm{Cd}, \mathrm{Cr}, \mathrm{Cu}, \mathrm{Mn}, \mathrm{Ni}, \mathrm{Pb}$ and $\mathrm{Zn}$ ) were determined by the A.A.S. method in 116 river water samples, of which 13 samples were collected from the granitic region and others from the green tuff region in Yamagata Prefecture. High concentration areas of the metallic elements were found in the east, southeast and central part of the survey area. In consideration of their flow rate, the mean concertrations of the metallic elements in river water were obtained. The mean values of $0.35 \mathrm{ppb}$ of $\mathrm{Cd}, 3.74 \mathrm{ppb}$ of $\mathrm{Cr}, 6.92 \mathrm{ppb}$ of $\mathrm{Cu}, 15.39 \mathrm{ppb}$ of $\mathrm{Mn}$, $3.32 \mathrm{ppb}$ of $\mathrm{Ni}, 5.45 \mathrm{ppb}$ of $\mathrm{Pb}$ and $17.26 \mathrm{ppb}$ of $\mathrm{Zn}$ were found in the green tuff region. The mean values of these elements in the granitic region was lower than that of the green tuff region except for $\mathrm{Cr}$.

Since it can be considered that these river water sampling sites are not affected by human activities, these values, except for lead, represent the minor metal concentration in close to its natural state.
\end{abstract}

\section{Introduction}

In a wide area extending from Hokkaido to the Tohoku District of Japan, strata deposited during the Miocene Epoch are characterized by green-colored tuff beds known as green tuff. In this green tuff region, there are many metal sulfide ore deposits including black ore. In the green tuff and its associated rocks (e.g. andesite, propyrite etc.), which are the country rock of black ore deposits, heavy metallic elements such as zinc, copper, lead, iron, manganese and so on generally occur. In discussing environmental pollution by heavy metallic elements originating from idle or abandoned ore mines, it is necessary to consider the contribution of heavy metals from these rocks, that is, their natural condition.

In the present study, the author demonstrates the distribution of some minor heavy metallic elements in river waters mainly from the green tuff region of Yamagata Prefecture from 1977 to 1980 , and reports on their natural background values.

\section{Materials and Methods}

\subsection{Sampling}

The location of sampling stations is shown in Fig. 1, in which hatched areas indicate the granitic region. Water samples were collected in the upper reaches of several tributaries of the River Mogami. These sampling stations are located about several hundred meters upstream of villages and mines if exist. Therefore these river waters can be considered to be free of

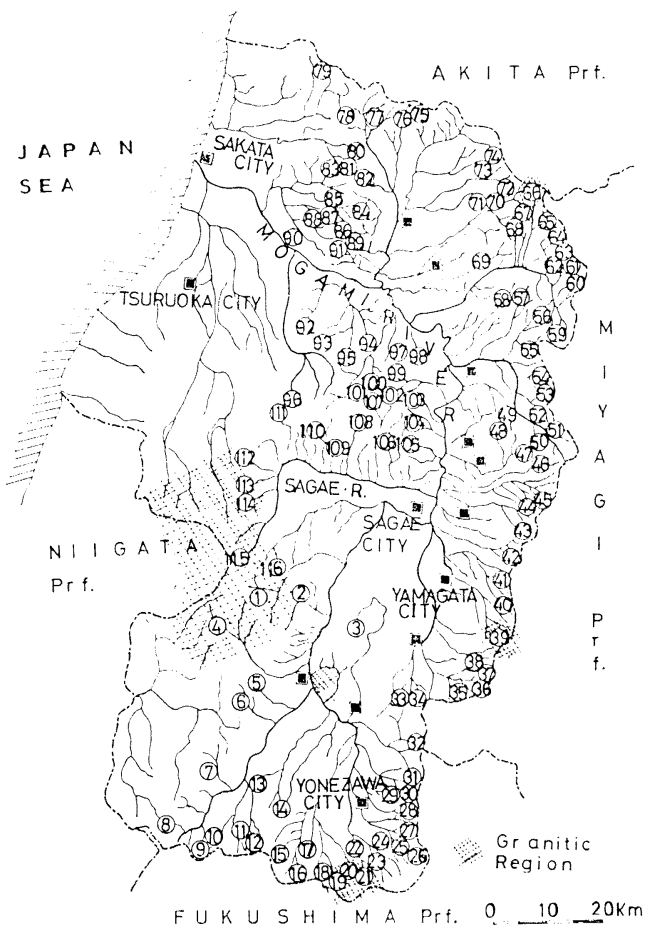

Fig. 1. Location of sampling sites in Yamagata Prefecture. 
man-made contamination deriving from community activities and mining.

Of a total of 116 sampling stations, 13 are located in the granitic region and the remainder are in the green tuff region. The samples were collected from July to November of 1977-1980. About 30 samples were collected in a year.

\subsection{Field work}

River water samples were collected at each site in two polyethylene bottles (1 liter ea.). One was acidified to $\mathrm{pH} 1$ by adding super special grade nitric acid and used for determination of heavy metals. Another served to analyze major chemical constituents. Temperatures of the air and river water and the flow rate of river water (using a digital flow meter model UC-2, Tamaya Co. Ltd.) were measured simultaneously.

\subsection{Analytical methods}

Minor metallic elements such as $\mathrm{Cd}, \mathrm{Cu}, \mathrm{Ni}$, $\mathrm{Pb}$ and $\mathrm{Zn}$ were determined by an atomic absorption spectrometer (Instrumentation Laboratory model IL-151) after solvent extraction by the APDC-MIBK method (CHIBA and Kuroda, 1972). The determination of $\mathrm{Mn}$ and $\mathrm{Cr}$ (VI) was carried out by the atomic absorption spectrometry with coprecipitation by iron (III) hydroxide.

Major constituents such as $\mathrm{Na}^{+}, \mathrm{K}^{+}, \mathrm{Ca}^{2+}, \mathrm{Mg}^{2+}$, $\mathrm{Cl}^{-}, \mathrm{SO}_{4}{ }^{2-}$ and alkalinity were determined by the routine analytical method.

\section{Results and Discussion}

\subsection{Results of analysis}

The concentration ranges, mean concentrations and standard deviations of major constituents

Table 1. Statistical data of analyzed results in river waters from tributaries of the River Mogami.

(1) Major constituents

\begin{tabular}{lccccccc}
\hline & $\mathrm{Na}^{+}$ & $\mathrm{K}^{+}$ & $\mathrm{Ca}^{2+}$ & $\mathrm{Mg}^{2+}$ & $\mathrm{Cl}^{-}$ & $\mathrm{SO}_{4}{ }^{2-}$ & Alkalinity \\
\hline Range (ppm) & $0.6-15.8$ & $0.2-4.8$ & $0.4-32.8$ & $0.1-5.0$ & $0.4-10.9$ & $0.2-61.9$ & $0.04-0.77$ \\
Mean $(\bar{x})(\mathrm{ppm})$ & 5.20 & 0.73 & 5.83 & 1.37 & 4.97 & 8.33 & 1.30 \\
s.d. $(\hat{\sigma})$ & 2.77 & 0.59 & 4.34 & 0.94 & 2.03 & 8.86 & 0.17 \\
Variance ( $(\hat{\sigma} / \bar{x})$ & 0.53 & 0.80 & 0.75 & 0.69 & 0.41 & 1.06 & 0.55 \\
& & \multicolumn{7}{c}{ (Granitic Region) } & & & \\
Range (ppm) & $1.5-3.3$ & $0.2-1.2$ & $3.0-10.0$ & $0.03-3.9$ & $1.9-5.6$ & $0.4-20.0$ & $0.13-0.4$ \\
Mean ( $(\bar{x})(\mathrm{ppm})$ & 2.54 & 0.53 & 5.35 & 0.64 & 3.68 & 3.55 & 0.29 \\
s.d. $(\hat{\sigma})$ & 0.83 & 0.31 & 2.11 & 1.01 & 1.27 & 5.12 & 0.09 \\
Variance $(\hat{\sigma} / \bar{x})$ & 0.33 & 0.58 & 0.40 & 1.57 & 0.34 & 1.44 & 0.31 \\
\hline \hline
\end{tabular}

(2) Trace metallic elements

\begin{tabular}{|c|c|c|c|c|c|c|c|}
\hline & $\mathrm{Cd}$ & $\mathrm{Cr}$ & $\mathrm{Cu}$ & $\mathrm{Mn}$ & $\mathrm{Ni}$ & $\mathrm{Pb}$ & $\mathrm{Zn}$ \\
\hline \multicolumn{8}{|c|}{ Green Tuff Region) } \\
\hline Range (ppb) & $0-6$ & $0-41$ & $0-111$ & $0-124$ & $0-63$ & $0-55$ & $1-288$ \\
\hline Mean $(\bar{x})(\mathrm{ppb})$ & 0.58 & 4.56 & 9.66 & 15.27 & 4.73 & 8.23 & 27.01 \\
\hline s.d. $(\hat{\sigma})$ & 0.94 & 5.84 & 13.47 & 27.67 & 9.38 & 11.85 & 39.46 \\
\hline Variance $(\hat{\sigma} / \bar{x})$ & 1.62 & 1.28 & 1.39 & 1.81 & 1.98 & 1.44 & 1.46 \\
\hline \multicolumn{8}{|c|}{ (Granitic Region) } \\
\hline Range (ppb) & $0-15$ & $0-15$ & $0-12$ & $0-46$ & $0-11$ & $0-12$ & $4-42$ \\
\hline Mean $(\bar{x})(\mathrm{ppb})$ & 0.15 & 5.00 & 5.23 & 6.92 & 2.46 & 4.31 & 10.23 \\
\hline s.d. $(\hat{\sigma})$ & 0.38 & 3.70 & 3.70 & 12.18 & 3.41 & 4.39 & 9.86 \\
\hline Variance $(\hat{\sigma} / \bar{x})$ & 2.53 & 0.74 & .071 & 1.76 & 1.39 & 1.01 & 0.96 \\
\hline
\end{tabular}

* The number of analyzed samples from the green tuff region and the granitic reagion tatals 103 and 13 , respectively. 
and minor metallic elements in river waters of the green tuff and granitic regions are shown in Table 1. In comparison with these mean concentrations of major constituents and the results of river waters in the Tohoku District published by Kobayashi et al. (1976), the former are lower than those of the latter. This comparison is reasonable because the samples under study were collected in the upper reaches of each river where effects of human activities are considered to be negligible. The mean concentrations of minor metallic elements in the green tuff region, except chromium, are higher than that of the granitic region, and the standard deviations of metal concentration in both regions are large. Figure 2 shows the frequency distributions of the minor metallic element concentration. Of course, the respective metallic elements have a different mean and standard deviation. As it is not easy to compare these different distribution patterns directly, the analytical data were normalized and classified into five classes.

The normalized data $\left(C_{\boldsymbol{A}}\right)$ are expressed as follows:

$$
C_{A}=\left(C_{A i}-x_{A}\right) / \hat{\sigma}_{A}
$$

where $C_{A i}$ is the concentration of metal $A$ in river $i, x_{A}$ is the mean concentration of metal $A$ in the green-tuff or granitic region and $\hat{\sigma}_{A}$ is the standard deviation of concentration of metal $A$.

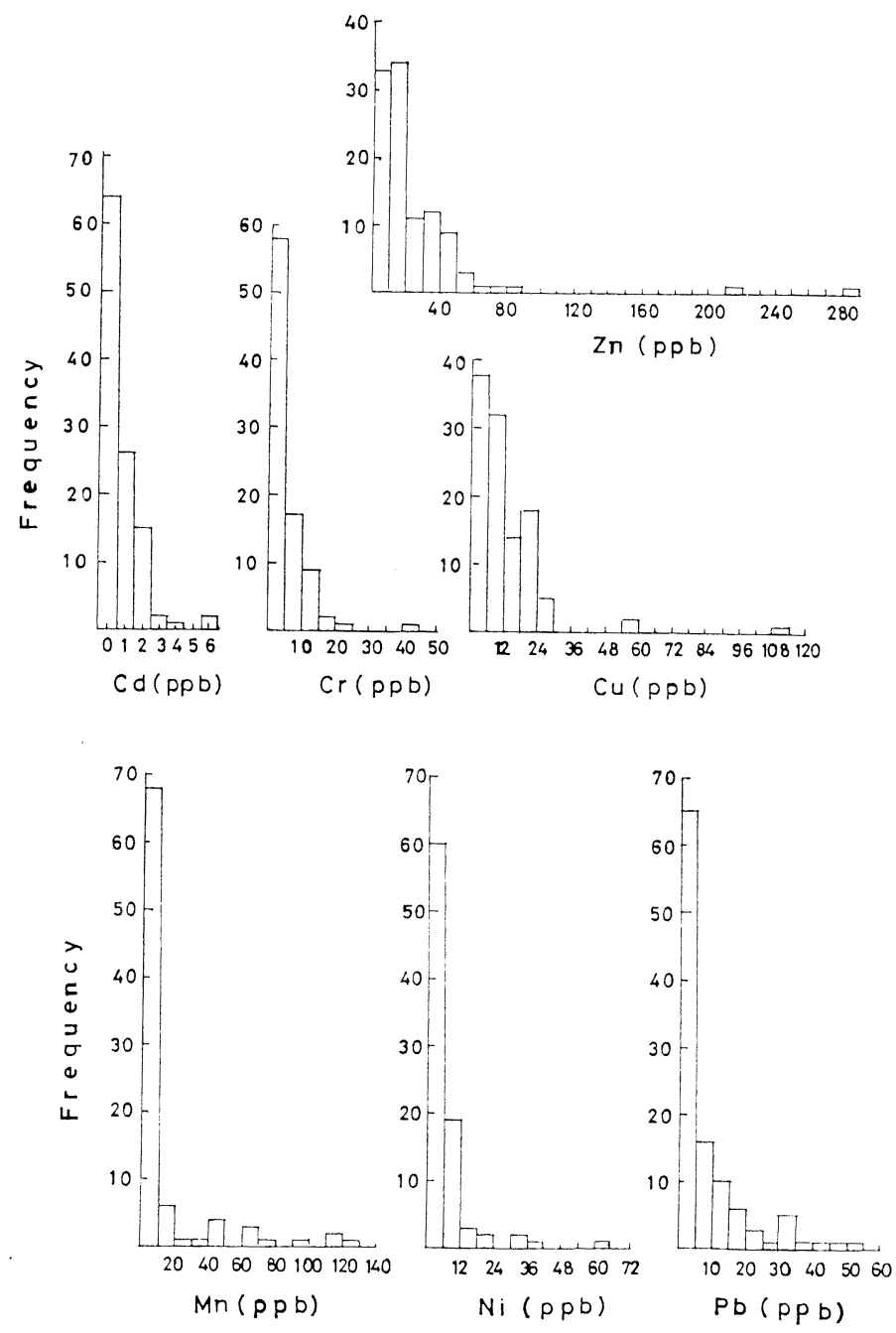

Fig. 2. Frequency distribution of minor metallic elements. 
This is the same manner as normalization of normal distribution.

As may be seen from Fig. 2, the frequency distribution of each metallic element is biased toward a lower concentration, so that it is closely a lognormal distribution. Therefore, the data were divided at the standard deviation (i.e., the value of 1 in normalized data) in the range before and after the mean concentration (i.e., 0 in normalized data) and narrower and wider than the standard deviation in the lower and the higher concentration ranges, respectively. The boundary of classes of normalized data and concentration levels is as follows:

\begin{tabular}{|c|c|}
\hline $\begin{array}{c}\text { (Class } \\
\text { boundary) }\end{array}$ & $\begin{array}{l}\text { (Concentration } \\
\text { level) }\end{array}$ (Symbol* \\
\hline$<-0.51$ & $\begin{array}{l}\text { No detectable or very } \\
\text { low concentration }\end{array}$ \\
\hline$-0.50 \sim-0.16$ & Low concentration \\
\hline$-0.15 \sim+0.85$ & $\begin{array}{l}\text { Approx. the mean } \\
\text { concentration }\end{array}$ \\
\hline$+0.86 \sim+2.00$ & High concentration \\
\hline$+2.01<$ & $\begin{array}{l}\text { Very high } \\
\text { concentraiton }\end{array}$ \\
\hline
\end{tabular}

\subsection{Concentration distribuion of each metallic element}

\subsubsection{Cadmium}

The cadmium concentration was found to range from 0 to $3 \mathrm{ppb}$. The distribution pattern of concentration of this element is shown in Fig. 3-1. The concentration of cadmium was almost zero in the upper reaches of the rivers located in the south and east area, where $65 \%$ of the stations had no detectable cadmium. Excepting the rivers flowing in cadmium polluted areas (Yamagata et al., 1975, КовaYASHI, 1978 and others), there are a few reports on cadmium in river waters. SAKINo et al. (1979) and ChayA et al. (1981) have reported that cadmium was not detected generally in the river water of the Kitakyushu district and Aichi Prefecture. It can be generally considered that the cadmium concentration in river waters is very low.

\subsubsection{Chromium}

The chromium concentration was found to

* These symbols are also used in the distribution pattern shown in Figs. 3 and 4, but in these figures the boundary of each class is expressed in $\mathrm{ppb}$. range from 0 to $41 \mathrm{ppb}$ and, with $97.4 \%$ of the samples showing the range between 0 and 16 ppb. Durum and HaffTy (1963) reported a median value of $5.8 \mathrm{ppb}$, ranging from 0.72 to $84 \mathrm{ppb}$ in large rivers of North America (Table 2 ). In a study of the stream supply of dissolved metals, KharKae et al. (1968) showed a mean $\mathrm{Cr}$ concentration of $1.4 \mathrm{ppb}$ in 12 rivers from U.S.A. and the world. The mean value of $\mathrm{Cr}$ in the present work is close to DuRum's value. However, it appears that these values are somewhat high in the present study. The distribution pattern of this element is shown in Fig. 3-2. The concentration of chromium is markedly high in the eastern area, especially in the Obanazawa area.

\subsubsection{Copper}

The copper concentration was found to range from 1 to $111 \mathrm{ppb}$, but the copper concentration in $97.4 \%$ of the samples was less than $30 \mathrm{ppb}$. SaKino et al. (1980), in their studies on heavy metal concentration in the Kitakyushu district, considered $5.6 \mathrm{ppb}$ of copper to be the unpolluted level for that area. The mean value of $9.66 \mathrm{ppb} \mathrm{Cu}$ for the green tuff region in the present study is higher than the value from the

Table 2. Minor elements in large river of North America.

\begin{tabular}{ccc}
\hline Elements & Median $(\mathrm{ppb})$ & Range $(\mathrm{ppb})$ \\
\hline $\mathrm{Ag}$ & 0.09 & $0-0.94$ \\
$\mathrm{Al}$ & 238 & $12-2550$ \\
$\mathrm{~B}$ & 10 & $1.4-58$ \\
$\mathrm{Ba}$ & 45 & $9-152$ \\
$\mathrm{Co}$ & 0 & $0-5.8$ \\
$\mathrm{Cr}$ & 5.8 & $0.72-84$ \\
$\mathrm{Cu}$ & 5.3 & $0.83-105$ \\
$\mathrm{Fe}$ & 300 & $31-1670$ \\
$\mathrm{Li}$ & 1.1 & $0.075-37$ \\
$\mathrm{Mn}$ & 20 & $0-185$ \\
$\mathrm{Mo}$ & 0.35 & $0-6.9$ \\
$\mathrm{Ni}$ & 10 & $0-71$ \\
$\mathrm{~Pb}$ & 4.0 & $0-55$ \\
$\mathrm{Rb}$ & 1.5 & $0-8.0$ \\
$\mathrm{Sr}$ & 60 & $6.3-802$ \\
$\mathrm{Ti}$ & 8.6 & $0-107$ \\
$\mathrm{~V}$ & 0 & $0-6.7$ \\
$\mathrm{Zn}$ & 0 & $0-215$ \\
$\mathrm{Aft}$ & &
\end{tabular}

* After Durum and Haffty (1963). 


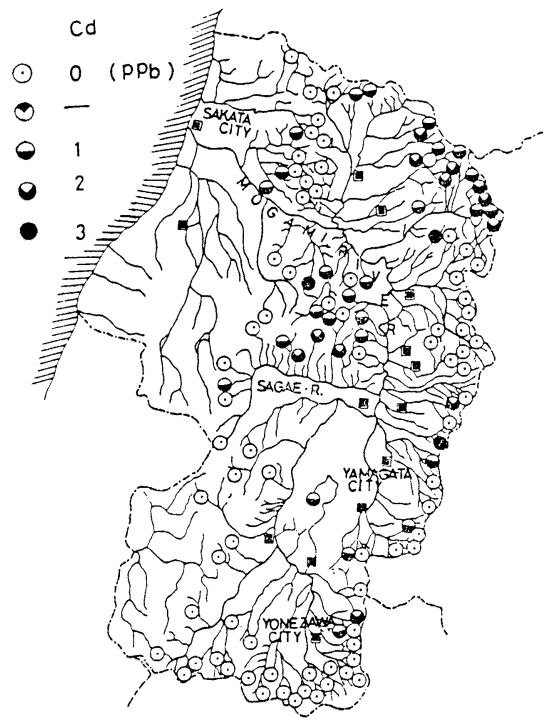

$3-1$

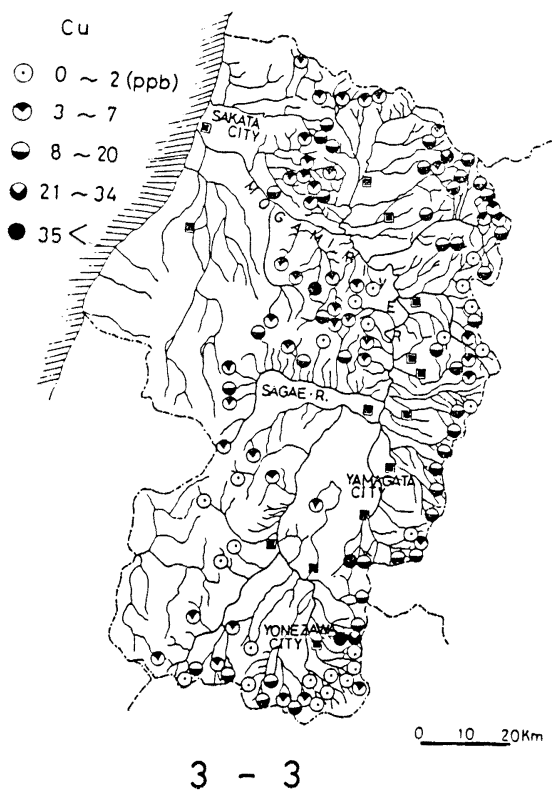

Fig. 3. Distribution patterns of concentration of $\mathrm{Cd}, \mathrm{Cr}, \mathrm{Cu}$ and $\mathrm{Mn}$ in river water of Yamagata Prefecture.

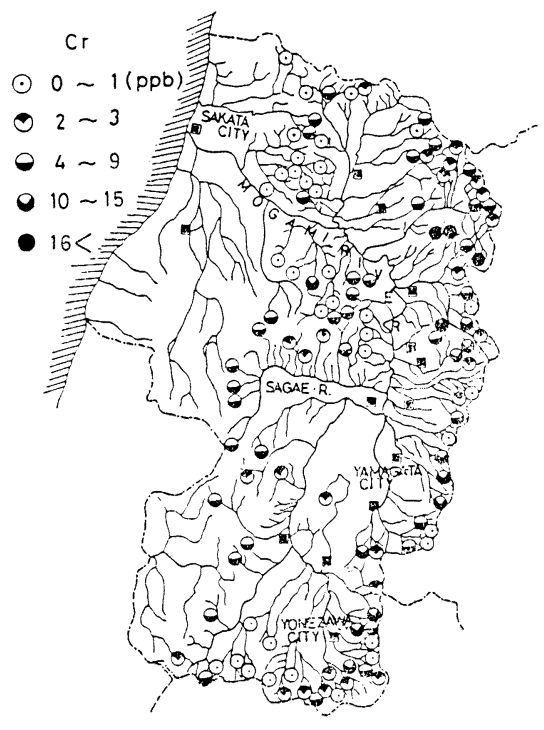

$3-2$

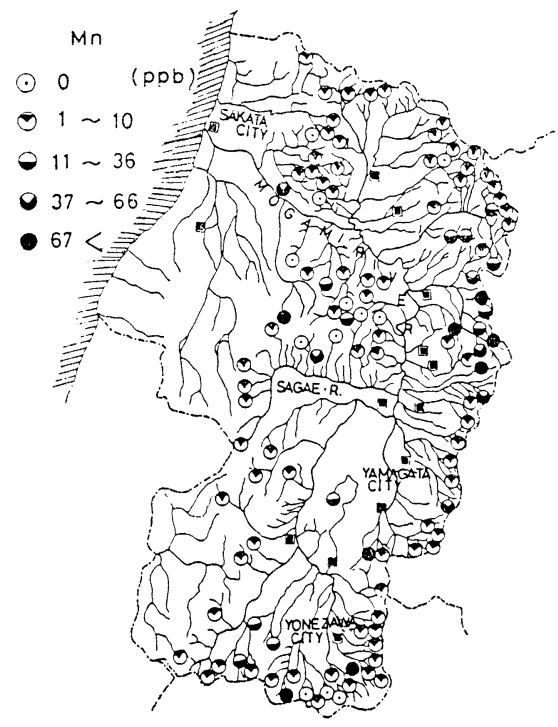

$3-4$
Kitakyushu district. The distribution pattern of copper is shown in Fig. 3-3. Higher concentration areas were found in the east and northeast area, and lower areas were found in the central and north area.

\subsubsection{Manganese}

The manganese concentration was found to range from 1 to $124 \mathrm{ppb}$. The manganese concentration in $91 \%$ of the samples was, however, less than $60 \mathrm{ppb}$, and $77 \%$ of them 

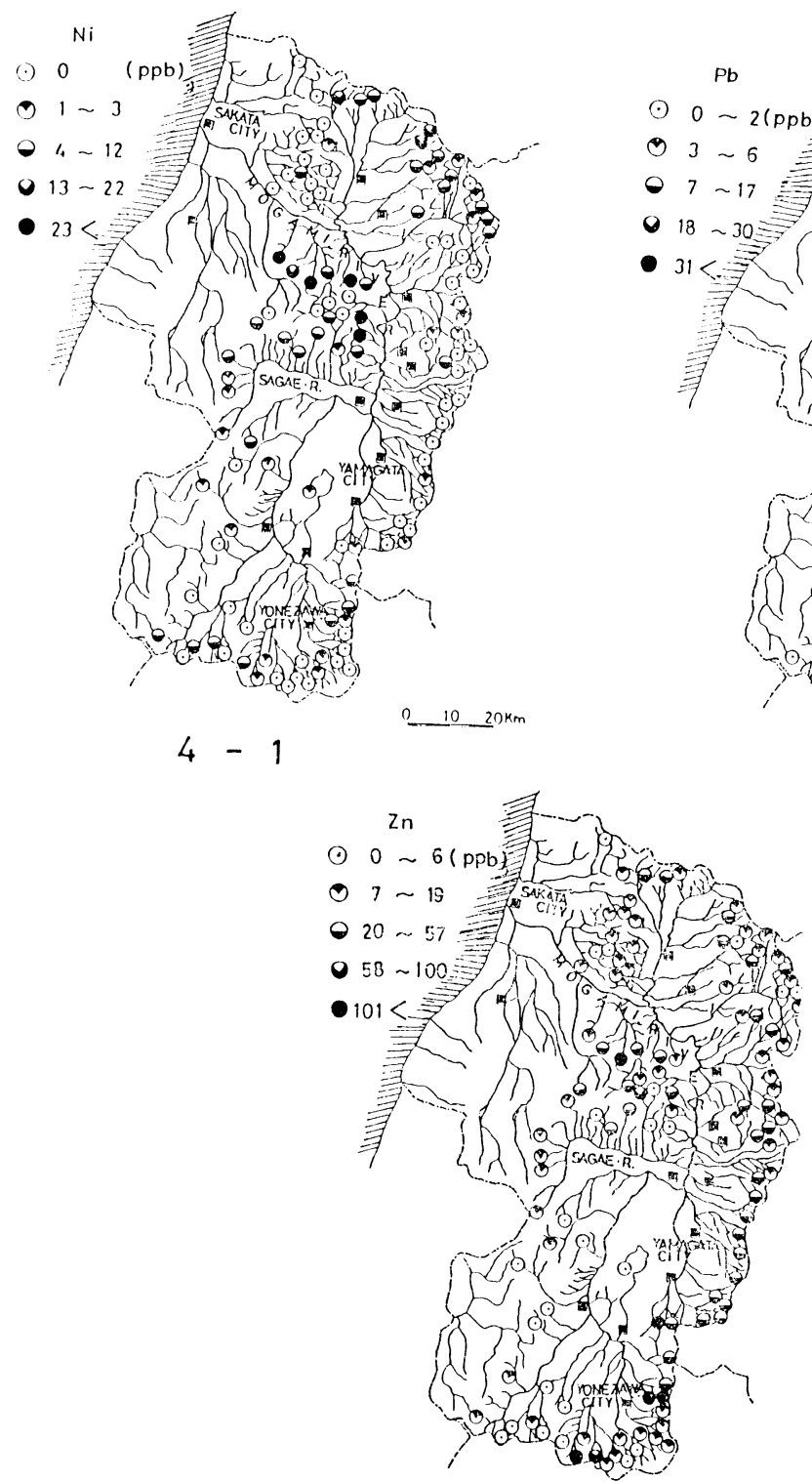

$4-3$

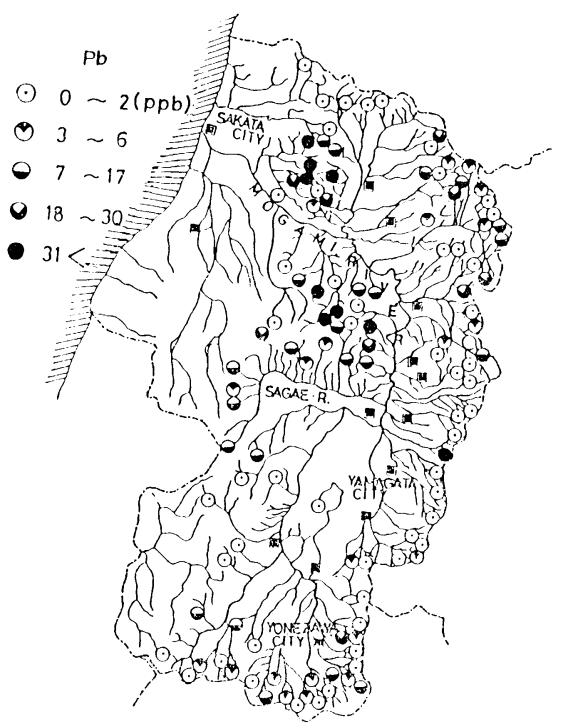

$4-2$

Fig. 4. Distribution patterns of concentrations of $\mathrm{Ni}, \mathrm{Pb}$, and $\mathrm{Zn}$ in river water of Yamagata Prefecture.

ranged less than $10 \mathrm{ppb}$. Comparison with Durum and Haffry's value (Table 2) indicates that the presently obtained is lower both in the green tuff and granitic regions than that given by Durum and HaffTy (1963). The distribution pattern of manganese is shown in Fig. 3-4. A higher concentration area was found in the east area, especially in the Murayama area.

\subsubsection{Nickel}

The nickel concentration was found to range from 0 to $63 \mathrm{ppb}$, but $97 \%$ of the samples showed less than $25 \mathrm{ppb}$. Compared with Durum and HaffTy's median value of $10 \mathrm{ppb}$ 
(Table 2), presently obtained is low both in the green tuff and granitic regions. The distribution pattern of nickel is shown in Fig. 4-1. A higher concentration area was found in the central area, but in almost all the stations nickel concentration was very low and not detected in $47 \%$ of the stations.

\subsubsection{Lead}

The lead concentration was found to range from 0 to $55 \mathrm{ppb}$, but $74 \%$ of the samples gave values less than $10 \mathrm{ppb}$ and $30 \%$ of the stations did not show lead content. SAKINo et al. (1980) considered a $\mathrm{Pb}$ value of $2.5 \mathrm{ppb}$ to be the unpolluted level in river waters of the Kitakyushu district. Durum et al. (1963) reported a $\mathrm{Pb}$ median value of $4.0 \mathrm{ppb}$ for large rivers of North America. Compared with these values, the mean value of $8.23 \mathrm{ppb}$ in the green tuff region is extremely high. There may have been lead contamination in the laboratory when the analysis was carried out, so this lead concentration is doubtful. The distribution pattern of lead is shown in Fig. 4-2. Relatively high concentration areas were found in the central and north area, but in the east area the lead level in river water was very low.

\subsubsection{Zinc}

The zinc concentration was found to range from 1 to $288 \mathrm{ppb}$, but $96 \%$ of the samples showed less than $100 \mathrm{ppb}$. Compared with the concentration of other heavy metallic elements in the river waters, the zinc concentration was high. According to Morita (1955), Japanese river waters contained zinc at a level of $1.5 \mathrm{ppb}$ in unpolluted water to $8200 \mathrm{ppb}$ in polluted water, and gave a mean concentration of $5 \mathrm{ppb}$. The zinc concentration in river waters of the green tuff region appeared to be extremely high. The distribution, pattern of zinc is shown in
Fig. 4-3. Almost one-third of the stations had a zinc content near the mean value, and only a few stations showed a particularly high zinc concentration over the mean value.

\subsection{Discussion}

\subsubsection{General distribution trend of minor metallic elements}

In surveying the regional distribution pattern of the minor metallic elements described above, high concentration areas of heavy metallic elements were found in the east, south-east and central areas of Yamagata Prefecture. In particular, a very high concentration of $\mathrm{Cd}, \mathrm{Cu}$, $\mathrm{Ni}, \mathrm{Pb}$ and $\mathrm{Zn}$ was observed at Station No. 95, of the Nagakura River. Although the source of these metals has yet to be determined, there are many idle or abandoned ore mines all over the area from Station No. 94 to No. 111 (see Fig. 1). It is likely that these ore deposits are responsible for these high values.

\subsubsection{Correlations between each metallic element}

The coefficients of correlation between various minor metallic elements in river water are shown in Table 3. A positive correlation was observed among $\mathrm{Cd}-\mathrm{Cu}-\mathrm{Cr}, \mathrm{Cr}-\mathrm{Mn}-\mathrm{Zn}$, and between $\mathrm{Cu}$ and $\mathrm{Zn}$ at a significant level of 0.01 . It is well known that these elements exist in significant quantities in green tuff (IRrYE, 1983), and, except for chromium ion, their ionic potential of 2.1-2.9 and belong to the soluble cation group. Therefore, it is reasonable that these elements behave dependently in water.

\subsubsection{Flow rate of minor metallic elements}

The total flux values of each element were calculated on the basis of analytical data and observed values of flow rate of river water at each sampling site. The flow rate in the range

Table 3. Correlation coefficients between various trace metallic elements.

\begin{tabular}{ccccccc}
\hline & $\mathrm{Cd}$ & $\mathrm{Cr}$ & $\mathrm{Cu}$ & $\mathrm{Mn}$ & $\mathrm{Ni}$ & $\mathrm{Pb}$ \\
\hline $\mathrm{Zn}$ & 0.222 & 0.256 & 0.784 & 0.319 & 0.186 & 0.109 \\
$\mathrm{~Pb}$ & 0.140 & 0.158 & 0.191 & 0.092 & 0.231 & \\
$\mathrm{Ni}$ & 0.156 & 0.052 & 0.202 & 0.135 & & \\
$\mathrm{Mn}$ & 0.050 & 0.272 & 0.127 & & & \\
$\mathrm{Cu}$ & 0.346 & 0.271 & & & & \\
$\mathrm{Cr}$ & 0.316 & & & & & \\
\hline
\end{tabular}

Significant level of $0.01 \quad \mathrm{r}=0.254$ 
Table 4. Total fluxes, mean fluxes and mean concentrations of minor metallic elements.

\begin{tabular}{|c|c|c|c|c|c|c|c|c|}
\hline & & $\mathrm{Cd}$ & Cr & $\mathrm{Cu}$ & $\mathrm{Mn}$ & $\mathrm{Ni}$ & $\mathrm{Pb}$ & $\mathrm{Zn}$ \\
\hline \multirow{3}{*}{$\begin{array}{l}\text { Green tuff } \\
\text { region }\end{array}$} & $\Sigma \mathrm{CiQi}^{*}$ & 11.64 & 124.98 & 231.41 & 514.72 & 111.10 & 182.40 & 577.44 \\
\hline & $\Sigma \mathrm{CiQi} / \mathrm{N}^{* *}$ & 0.12 & 1.24 & 2.29 & 5.10 & 1.10 & 1.81 & 5.72 \\
\hline & $\Sigma \mathrm{GiQi} / \Sigma \mathrm{Qi}^{* * *}$ & 0.35 & 3.74 & 6.92 & 15.39 & 3.32 & 5.45 & 17.26 \\
\hline \multirow{3}{*}{$\begin{array}{r}\text { Granitic } \\
\text { region }\end{array}$} & $\Sigma \mathrm{CiQi}^{*}$ & 1.78 & 91.39 & 51.66 & 103.44 & 54.93 & 73.15 & 122.43 \\
\hline & $\Sigma \mathrm{CiQi} / \mathrm{N}^{* *}$ & 0.14 & 7.30 & 3.97 & 7.96 & 4.23 & 5.63 & 9.42 \\
\hline & $\Sigma \mathrm{GiQi} / \Sigma \mathrm{Qi}^{* * *}$ & 0.10 & 4.94 & 2.79 & 5.59 & 2.97 & 3.95 & 6.61 \\
\hline
\end{tabular}

* $\mathrm{Ci}$ is the concentration of each metal in the river " $\mathrm{i}$ ", $\mathrm{Qi}$ is the flow rate of the river $\mathrm{i}$ at the sampling site and $\mathrm{N}$ is the number of sampling sites.

** Number of $\mathrm{N}$ are 103 and 13 in green tuff and granitic region respectively.

*** Values of the sum of the flow rate are $33.45 \mathrm{~m}^{3} \mathrm{sec}^{-1}$ and $18.51 \mathrm{~m}^{3} \mathrm{sec}^{-1}$ in green tuff and granitic region respectively.

of $0.01-1.00 \mathrm{~m}^{3} \mathrm{sec}^{-1}$ was obtained at $87 \%$ of the sampling sites. The highest value was $3.1 \mathrm{~m}^{3} \mathrm{sec}^{-1}$ and the lowest value was $0.001 \mathrm{~m}^{3}$ $\mathrm{sec}^{-1}$ in the Asahi River (No. 1) and the Nitto River (No. 48), respectively. In Table 4, the upper values in the columns representing the green tuff and granitic region are the overall flux of each element in the respective rivers (i.e., the total flux of each element). If one estimates the total flux of the respective elements in one year, the total flux of cadmium is about $0.4 \mathrm{t} \cdot \mathrm{y}^{-1}$, chromium about $3.9 \mathrm{t} \cdot \mathrm{y}^{-1}$, copper about $7.3 \mathrm{t} \cdot \mathrm{y}^{-1}$, manganese about $16.2 \mathrm{t} \cdot \mathrm{y}^{-1}$, nickel about $3.5 \mathrm{t} \cdot \mathrm{y}^{-1}$, lead about $5.8 \mathrm{t} \cdot \mathrm{y}^{-1}$ and zinc about $18.2 \mathrm{t} \cdot \mathrm{y}^{-1}$.

\subsubsection{Natural background values of minor metallic elements}

As mentioned previously, sampling stations in this study are not considered to be affected by human activities. Thus the analytical values for these water samples are the natural background values of these rivers. Since the total flux values shown in Table 4 were calculated on the basis of these background values, these flux levels are represent the natural background flux values.

To divide these total flux values by the total number of sampling stations, the mean flux values were obtained (Table 4 ). Moreover, to divide the total flux value of each metal by the total flow rate of river water at sampling sites, the mean concentrations were determined. These mean concentrations were somewhat lower than thous shown in Table 1, which were obtained by dividing the sum of the metal concentration in each site by the number of sampling stations. For the flow rate of river water at each sampling station, the author considered it more trustworthy to use the mean value based on the flow rate of river waters than the mean value based on the number of sampling stations. Therefore, it is suggested that these values shown in Table 4, with the exception of lead, are the natural background values of minor metallic elements in the green tuff and granitic region.

\section{Acknowledgements}

The author is greatly indebted to Mr. S. Konno, Mrs. Y. Ozeki (né Hosoya), Mr. I. TAKahashi and Mr. M. Yokobori for their kind technical assistance in the course of this study.

\section{摘 要}

山形県最上川の各支流の上流地点 116 箇所（内 103 筒所はグリーンタフ地域で，他は花崗岩地域を流れ る.) において採水した試料について，重金属 (Cd, $\mathrm{Cr}, \mathrm{Cu}, \mathrm{Mn}, \mathrm{Ni}, \mathrm{Pb}$ 及び $\mathrm{Zn}$ ) を原子吸光分析法で 定量した. 重金属の高濃度地帯は県の東部, 南西部及 ぴ中央部の地域であった，河川水の流量をも考慮に入 れてこれらの重金属の平均濃度を求め，グリーンタフ 地域に打いて Cd 0.35 ppb，Cr 3.74 ppb，Cu 6.92 ppb, Mn 15.39 ppb, Ni 3.32 ppb, Pb 5.45 ppb 及 び Zn $17.26 \mathrm{ppb}$ を得た. 花崗岩地域では Cr を除 いて何れの元素もこれらの值よりも低かった. 試料水 を採取した地点は, 何れも人類活動の影響が殆んど無 いと考えられる処なので，上記の值は，分析の際疑間 のあった $\mathrm{Pb}$ を除いて, グリーンタフ地域河川の重金 属濃度のバックグラウンド值と考学てよいであろう。 


\section{References}

Ghaya, K., B. Tomita, M. Shimizu, S. Ohnuma, T. Shoka and N. Hamamura (1981): Chemical Composition of River Waters in Aichi Prefecture. Jap. J. Limnol., 42: 131137 (in Japanese).

Chiba, M. and M. Kuroda (1972): Cd, Zn, $\mathrm{Pb}, \mathrm{Cu}$ and $\mathrm{Ni}$ in water. Kohgai Bunseki Shishin (Guide of analysis for environmental pollution) 4-Water and Soil, 1-a. Kyoritsu Shuppan.

Durum, W. H. and J. Haffty (1963): Implications of the minor element content of some major streams of the world. Geochim. Cosmochim. Acta, 27: 1-11.

KHARKar, D. P., K. K. TUREkIAN and K. K. Bertine (1968): Stream supply of dissolved silver, molybdenum, antimony, selenium, chromium, cobalt, rubidium and cesium to the oceans. Geochim. Cosmochim. Acta, 32: 285298.

Kobayashi, J. (1978): Pollution by cadmium and the itai-itai disease in Japan. p. 199-260. In: F. W. Oeнme (ed.), Toxicity of heavy metals of the environment, Part 1. Marcel Dekker Inc.

Kobayashi, J., F. Morit, S. Muramoto, S. Nakas hima, Y. Urakami, H. Nishizaki, H. Teraoka and N. Nagao (1976): Chemical investigation on the quality and characteristics of river waters in the Tohoku disrict. Nohgaku Kenkyu, 55, No. 3: 103-144 (in Japanese).

Iriye, T. (1983): On the content of Trace metallic elements in green tuff, p. 257-275. In: S. S. Augustithis (ed.), The Significance of Trace Elements in Solving Petrogenetic Problems and Controversies. Theophrastus Publication S.A. (Athens).

Morita, T. (1955): Distribution of copper and zinc in various phases of the earth materials. J. Earth. Sci. Nagoya Univ. 3-33.

Sakino, H., A. Hashimoto, Y. Uchimura, S. Tateishi and T. Akiyama (1980): Note on heavy metal concentration in the aquatic environment of the Kitakyushu District in Japan, 1976-1977. Waer Res., 14: 12331237.

Yamagata, N., T. Iriye, M. Shima and T. Goto (1975): Translocation of cadmium from a mining district to paddy fields. Bull. Inst. Publ. Health, 24(1): 35-49.

(著者: 入江敏勝, 山形大学理学部化学教室, $\overline{\mathbf{T}} 990$ 山形市小白川町一丁目; Toshikatsu IRIVE, Department of Chemistry, Faculty of Science, Yamagata University, Kozirakawa-machi 1-chome, Yamagata 990)

Accepted: 1 Aug. 1984 